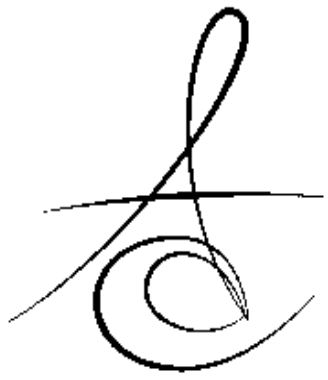

Makale Kodu/Article code: 1537

Makale Gönderilme tarihi: 19.02 .2014

Kabul Tarihi: 02.07.2014

\section{AKRİLİK REZİNLER, YUMUŞAK ASTAR MATERYALLERİ VE DOKU DÜZENLEYİCİLERİN ÇÖZÜNÜRLÜK ÖZELLİKLERİ}

\section{SOLUBILITY OF ACRYLIC RESINS, SOFT DENTURE RELINING MATERIALS AND TISSUE CONDITIONERS}

Yrd. Doç. Dr. Işıı Damla ŞENER YAMANER* Yrd. Doç. Dr. Zeynep TUTAL*

\section{ÖZET}

Günümüzde Avrupa da ve endüstriyel olarak gelişmekte olan bölgelerde her ne kadar dişsizlik oranı ve diş kayıpları son yıllarda azalıyor ve implant tedavileri daha popüler tedaviler haline geliyor olsa da önümüzdeki yıllarda da bölümlü veya tam dişsiz hastalar konvansiyonel prostodontik tedaviye intiyaç duyacaklardır. Yumuşak astar materyalleri maxillofasi yal ve tam protezlerde tutuculuğu arttırmak, reziduel alveolar kretlerin ilerlemiş rezorbsiyonlarında ve travmatize destek dokuların tedavisinde hastaya konfor sağlamak amacıyla sıklıkla kullanılırlar. Doku düzenleyiciler ise kuvvet dağılımını dengelemek amacıyla protez iç yüzeyine uygulanırlar. Akrilik rezinlerin, yumuşak astar materyallerinin ve doku düzenleyicilerin zaman içerisinde yapılarının bozunmasına ve fonksiyonlarının olumsuz etkilenmesine neden olan en önemli özelliklerden biride çözünürlük özelliğidir. Bu makalede hareketli protezlerin kaide materyali olan akrilik rezinlerin, yumuşak astar materyallerinin ve doku düzenleyicilerin çözünürlük özellikleri incelenmiştir.

Anahtar kelimeler: Akrilik rezin, Astar materyalleri, Çözünürlük

\section{ABSTRACT}

In recent decades, the prevalence of edentulism and the incidence of tooth loss has decreased in Europe and other industrialized regions; furthermore oral implants are becoming more popular. However in coming decades most patients with complete or partial edentulism will continue to receive conventional prosthodontic treatment. Soft denture relining materials are often used in order to gain retention for maxillofacial and complete dentures, to treat the traumatic supporting tissues to provide the comfort for patients and of improved resorbtion of residual alveolar crets. Tissue conditioners are also used for balancing the distribution of the loads. The solubility property is one of the main reason of the the structure of the acrylic resins, soft relining materials and tissue conditioners. In this article the solubility property of the acrylic resins, soft denture relining materials and tissue conditioners are reviewed. Solubility

Key Words: Acrylic resin, Relining materials,

hareketli/sabit daimi protezleri tamamlanana kadar geçen sürede hastalar geçici akrilik protezler kullanmaktadırlar. ${ }^{2}$ Hayat kalitesi açısından bu kadar çok insanı etkileyen protezlerin kaide materyallerinin estetik ve fonksiyonel olmasının ne kadar önemli olduğu şüphe götürmez bir konudur.

Akrilik rezinler 1930 'lu yıllardan itibaren Diş hekimliğinde sıklıkla kullanılmaktadırlar. Akrilik rezinler, akrilik asit $(\mathrm{CH} 2=\mathrm{CHCOOH})$ ve metakrilik asit $[\mathrm{CH} 2-$ $\mathrm{C}(\mathrm{CH} 3) \mathrm{COOH}$ ]'ten üretilmişlerdir. ${ }^{3}$ Akrilik asit de

İstanbul Aydın Üniversitesi Diş Hekimliği Fakültesi, Protetik Diş Tedavisi Anabilim Dalı

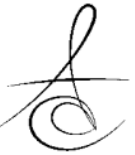


metakrilik asit de katılma polimerizasyonu ile polimerleşirler. Bu poliasitler karboksilik asit gruplarından dolayı gözenekli bir yapıyada olup, su çekme özelliğine sahiptirler. Su, polimer zincirlerini ayırarak rezinin yumuşamasına ve dayanıklıı̆̆ının azalmasına sebep olur. ${ }^{3}$

Valittu ve ark., ${ }^{4}$ suyun, polimer yapısı ile etkileşerek plastikleştirici etki yaptığını, protez kaide polimerlerinin su emmesinin içerisindeki çapraz bağlantı ajanının tipine bağlı olduğunu belirtmişlerdir.

Polimetilmetakrilat uzun dönemde yavaş su emmektedir. Su emilimi esas olarak rezin moleküllerinin polar özelliklerinden kaynaklanır. Emilim mekanizmasının difüzyon kurallarına göre su difüzyonundan kaynaklandığı tespit edilmiştir. Akrilik rezinlerde su emilimi ağırlıkta \%1 artma ve \% 0.23'lük bir genleşmeye sebep olmaktadır. ${ }^{3}$

Klinik kullanımda akrilik rezinler tükrükle temas ederek veya protez temizleme preparatlarına ve/veya suya batırılarak sıvı ortama temas ederler. Bazı araştırmacılar su moleküllerinin polimer matriks içerisine penetre olarak plastizer gibi görev yaptığını ve akrilik kaidelerin ve yumuşak astar materyallerinin mekanik özelliklerini olumsuz olarak etkilediği belirtmektedirler. $^{5-7}$ Tam tersine bazı araştırmacılar ise su gibi küçük plastizer moleküllerin ortamda bulunmasının enerjiyi dağıtan moleküler harekete yardımcı olduğunu bildirmektedirler. ${ }^{8}$

Akrilik rezin suya batırıldığında 2 fenomen doğal olarak gerçekleşir; su emilimi ve residüel monomer salınımı. Su molekülleri polimer ağına yerleşir ve polimer zincirlerini hareket ettirir, zincirler arasındaki moleküler kuvvetleri azaltarak materyali zayıflatır. Salınan rezidüel monomerlerde akriliği zayıflatan bir diğer etken olarak ortaya çıkar. Monomer salınımı ve su absorbsiyonu zamana bağlı etkilerdir. Bundan dola- yı kaide polimerindeki moleküllerin miktarı zaman içerisinde değişir. ${ }^{5-7,9}$

Çözünürlük ise polimerden çözünen maddelerin salınması olarak tanımlanır. ${ }^{10}$ Rezinlerin ağız içinde temas ettikleri birçok sıvıda çözünmemesi istenir. Polimetilmetakrilat, kloroform gibi birçok çözücüde çözündüğü halde ağız ortamında, içerisinde çözünmediği sıvılarla karşılaşmaktadır. ${ }^{1}$ Bununla beraber monomer ve pigmentlerin çözünmesi nedeniyle ağırlık kaybı oluşmaktadır. Çözünürlük; çözünüm süresi, çözünüm ortamındaki solüsyonun konsantrasyonu, ortamın pH'sı, rezinin şekli ve kalınlığı, maddenin içindeki monomer yapısı, çapraz bağlantı derecesi, doldurucu tipi ve hacmine bağlı olabilir. ${ }^{10}$ Protez kaidesinden en çok serbest monomer, ${ }^{11,12}$ az miktarda da başlatıcılar ve plastikleştiriciler ${ }^{10,13}$ çözünür. Serbest monomer miktarıyla, örneklerde çözünürlük testi sonucu oluşan ağırlık kaybı arasında bir korelasyon olduğu iddia edilmektedir. ${ }^{10}$ En büyük artık monomer salınımının, ilk 5 günde olduğu bildirilmektedir. ${ }^{13}$

Akrilik rezin kaidelerden çözünen materyallerin kaideye komşu oral mukozal dokulara alerjik cevap oluşturacak etkileri mevcuttur. ${ }^{14}$ Alerjik cevabı oluşturan başlıca yapılar kaideden suya ve tükrüğe çözünen artık metilmetakrilat monomerleri ve formaldehittir. ${ }^{15}$

Akrilik rezinden çözünen formaldehitin patojenik potansiyeli Lewis ve Chestner tarafından deney hayvanlarına akrilik rezin implante edilmesi ile araştırılmıştır. Araştırmanın sonucunda formaldehidin mukozada sadece irritasyon yaratmadığı, düşük konsantrasyonlarda bile alerjik reaksiyona neden olduğu tespit edilmiştir. $^{16}$

Hareketli protezlerin doku yüzeylerindeki plak oluşumu protez stomatitlerinin başlıca sebebidir. ${ }^{17}$ Fırça kullanımı plağın çıkarılmasında en etkili ve protez materyaline en az zarar veren yöntemdir ancak büyük oranda hasta uyumu gerektirir. ${ }^{18}$ Özellikle el becerisinin azaldığı yaşı ve engelli protez kullanıcılarında etkili plak uzaklaştırma işlemi zorlaşır. ${ }^{19,20-22}$ Efervesanlar genellikle mikroorganizmalara etki eden oksit ajanlar içerirler. ${ }^{19,20}$ Köpürme özellikleri sayesinde kontaminantları protez yüzeyinden kolaylıkla uzaklaştırabilirler. ${ }^{19-21}$

Turgut ve ark. $^{23}$ sıklıkla kullanılan bazı protez temizleme ajanlarının uzun dönem kullanımlarının, Enjeksiyon sistemi ile hazırlanan otopolimerizan kaide rezini (PalaXpress) ile klasik ISI ile polimerize olan kaide rezininin (Meliodent) su emilimi ve çözünürlüğü üzerine etkilerini değerlendirdikleri çalışmalarının sonucunda temizleme preparatlarının her iki akrilik rezinin su emilimini değiştirmediğini, Regadont med ve Blenda dent temizleme preparatlarının uzun dönem kullanımının, otopolimerizan akriliklerin çözünürlüğünü önemli derecede arttırdığını ve bu protezlerin dirençlerini olumsuz yönde etkileyebildiğini tespit etmişlerdir.

Ural ve ark. ${ }^{24}$ protez temizleme ajanlarının uzun dönem kullanımlarının Cr-Co ve konvansiyonel akrilik rezinin yüzey pürüzlülüğüne etkilerini inceledikleri çalışmalarında da yine benzer olarak efervesan tabletlerin ve sodyum hipoklorit solusyonlarının akrilik 
Atatürk Üniv. Diş Hek. Fak. Derg.

J Dent Fac Atatürk Uni

Cilt:25, Sayı: 1, Yıl: 2015, Sayfa: 144-152

rezinin direncini olumsuz yönde etkileyebildiğini tespit etmişlerdir.

Nalbant ve Burgaz ${ }^{12}$ çalışmalarında enjeksiyon sisteminde geleneksel yönteme göre daha kompakt bir yapının oluştuğunu, daha düşük su emilimi ve değerlerinin ortaya çıktığını belirtmişlerdir. Polat ve ark. ${ }^{25}$ da yapmış oldukları çalışmada yine enjeksiyon akriliğinin su emilimi ve çözünürlük değerlerini geleneksel mufalalama yöntemine göre daha düşük olarak bulmuşlardır.

Tsuchiya ve ark. ${ }^{14} 1994$ yılında yayınladıkları çalışmalarında; 3 farklı rezin; Rebaron No.3 pembe (GC Dental Ind.,Tokyo,Japan) otopolimerizan rezin, Acron No.8 pembe (G-C Dental Ind.) ISI ile polimerize akrilik rezin, Acron MC No.8 pembe (G-C Dental Ind.) mikrodalga ile polimerize rezinin çözünürlüğünü, rezin diskler hazırlayarak, diskleri 2,0 ml.tükrüğe ve yapay tükrüğe batırarak ve otopolimerize rezin diskleri sağlıkl erkek hastaların ağız içine yerleştirip, hastalardan 5 dakikalık periyodlarda 30 saniyede bir tükrük alınarak, in vivo ve in vitro olarak karşılaştırmışlar ve çalışmalarının sonucunda; disklerin batırıldığı ilk günde rezin-

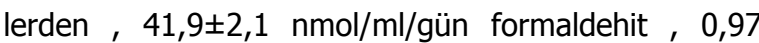
$\pm 0.06 \mathrm{nmol} / \mathrm{ml} /$ gün metilmetakrilat çözündüğü, mikrodalga ile polimerize rezinin çözünürlüğünün ise her iki materyal içinde yarısı kadar değerlerde tespit edildiği belirtilmiştir. Ayrıca formaldehit ve polimetilmetakrilat çözünmesinin azalmasını sağlamak için akrilik rezin protezlerin, kullanımı öncesinde 50 derecede suda bekletilmeleri gerektiği, 50 derecede bekletildiğinde artık metilmetakrilat konsantrasyonunun $1 / 4$ oranında azaldığı ve ağız içerisindeki çözünmenin, önce çözünme için bekletilen suyun ISıSı ile ters orantılı olduğu, ISI azaldıkça ağız içerisindeki çözünme miktarının arttığı sonucuna ulaşmışlardır. ${ }^{15}$

Formaldehit ve polimetilmetakrilat çözünmesinin azalması için akrilik rezin protezlerin, kullanım öncesinde sıcak suda bekletilmeleri gerektiği çalışmalarda belirtilmektedir. ${ }^{26}$

Akrilik rezinlerde su emilim özelliği PMMA moleküllerinin polaritesi ve su moleküllerinin polimer zincirlerinin arasındaki boşluk alanlarına difüzyonundan etkilenmektedir. ${ }^{27}$ Ürethan dimetakrilat monomerleri moleküler yapılarında 2 hidrofilik ürethan grubu bulundururlar. Isı stresi, polimer zincirleri arasındaki mesafeyi arttırarak polimerin su emme özelliğini arttırır. ${ }^{28}$ Isı derecesinin artması su moleküllerinin akrilik rezin içerisine diffüzyonunu hızlandırır. ${ }^{29}$
ŞENER YAMANER, TUTAL, TUNCER

Akrilik rezinlerin çözünürlüğü ile ilgili bir diğer çalışmada Rahal ve arkadaşlarının ${ }^{15} 2004$ yılında yayınladıkları çalışmadır. Cilalama metodlarının akrilik kaideli protezlerin çözünürlüklerine olan etkisinin incelendiği çalışmada; her gruptan 20 adet olmak üzere 80 adet; Classico (CL), QC 20 (QC), Acron MC (AC) , Onda Cryl (ON) akrilik rezin numune, mekanik cilalama $(320,400$ ve 600 grenlik aşındırma kağıtları ile) veya kimyasal cilalama (yaklaşık 75 derecede ısıtılmış monomer sıvısında kimyasal cilalayıcıda) metodlarına tabi tutulmuştur. Sonuç olarak en düşük çözünürlük değerleri, mekanik cilalama yapılan Acron MC (AC) ve kimyasal cilalama yapılan QC 20 (QC) ile elde edilmiştir. Mekanik olarak cilalanan akrilik rezinler arasında Classico $(\mathrm{CL})$ en yüksek çözünürlüğü gösterirken kimyasal olarak cilalananlar arasında en yüksek çözünürlüğü classico (CL) ve Acron MC göstermiştir. Mekanik cilalama ile elde edilen çözünürlük değerleri tüm akriliklerde kimyasal cilalama ile elde edilen değerlerden düşük bulunmuştur.

Akrilik rezinlerin çözünürlüğü ile ilgili yapılan az sayıdaki çalışmalardan biri de Lai ve ark. ${ }^{30} 2004$ yılında yayınladıkları mikrodalga enerjisi ile polimerize edilen akrilik rezinlerdeki çözünürlüğün incelendiği çalışmadır. Araştırmacılar, çalışmada Samsung MW- 3190T (Korea) model mikrodalga firınında, 80, 160, 240 ve 560 $\mathrm{W}$ da, 15, 10, 7, 2 dak. polimerize edilen akrilik rezinlerin çözünürlüklerini incelemişler ve çözünmeyen ağırIık yüzdesine bakarak mikrodalga enerjisi ile akrilik rezinin polimerizasyonun yeterli olduğu sonucuna varmışlardır.

Pfeiffer ve ark. ${ }^{31} 2004$ yılındaki çalışmalarında ise hipoalerjik materyal olarak bildirilen; Sinomer (ISI ile polimerize, modifiye metakrilat), Polyan (termoplastik, modifiye metakrilat), Promysan (termoplastik, enterefitalat bazlı) ve Mikrobase (mikrodalga ile polimerize, poliuretan bazlı) ile kontrol grubu olarak Paladon 65 (ISı ile polimerize, metakrilat) in çözünürlüklerini her gruptan 5 adet olmak üzere disk şeklinde numunelerle incelemişlerdir. Çalışmada; ISO 1567'ye göre suda bekletilen, çözünen materyaller $1,6 \mu \mathrm{g} /$ $\mathrm{mm}^{3}$ değerini aşmaması gerektiği belirtilmiş ve 5 numuneden en az 4 tanesinin bu koşula uygun olması gerektiği, 2 tanesi bu koşulları sağlamıyorsa akrilik rezin grubunun başarısız kabul edildiği ifade edilmiştir. Çalışmanın sonucunda; Sinomer (ISI ile polimerize, modifiye metakrilat) hariç tüm kaide rezinleri ISO 1567 nin koşulu olan $0,31 \pm 0,02 \%$ MMA monomer salınım 
miktarını sağlamış olarak bulunmuştur. Ayrıca hipoalerjik kaide materyallerinin (Microbase, Polyan, Promysan ve Sinomer) suda çözünürlüklerinin PMMA kaide materyalinden belirgin şekilde az olmadığı da tespit edilmiştir.

Vallıttu ve ark, ${ }^{32}$ çalışmalarında üretan ve metilmetakrilat oligomerlerinden oluşmuş polimer tanecikleri ve matrix polimerinden oluşan ve cam fiberlerle güçlendirilmiş, Sinomer kaide rezinin çözünürlüğünü incelemişler ve çalışmanın sonucunda Sinomer kaide rezininin çözünürlüğünü $1,52 \mu \mathrm{g} \mathrm{mm} \mathrm{m}^{-3}$ olarak tespit etmişlerdir. Kullanım sürecinin başlangıcında protezden çözünen artık monomerlere karşı alerjik reaksiyon veren bireylerde kullanılabilir "artık MMA-free" olarak pazarlanan Alldent Sinomer kaide rezin materyalinin de MMA monomerleri gibi suya çözündükleri ve alerjik bireylerde kullanılırken dikkat edilmesi gerektiği belirtilmiştir.

Takahashi ve ark. ${ }^{33}$ akrilik rezin kaideler ile yumuşak astar materyallerinin kimyasal yapıları ve su emilim özelliklerindeki farklılıkları nedeniyle suya batırılma işleminden farklı etkilendiklerini belirtmiştirler. Akrilik rezinlerin mekanik direnci materyalin kendi iç direnci ve emdikleri su miktarına bağlıdır. Otopolimerizan chairside rezinler ile sıvı fazdan oluşan metilmetakrilat bazlı konvansiyonel akrilik rezinler bu nedenle farklılık gösterirler.

\section{Yumuşak Astar Materyalleri ve Geçici Yumuşak Astar Materyalleri (Doku Düzenleyiciler)}

Yumuşak astar materyallerinin klinik olarak ilk kullanımı 1943 yılında rapor edilmiştir. ${ }^{33}$ Protetik diş hekimliğinde, dişsiz kret bölgelerinin maruz kaldığı okluzal kuvvetlerin kaide materyali altında kalan yumuşak dokulara iletilirken yükün azaltılmasında ve yükün dağılımının dengelenmesinde klinik önem taşıyan yumuşak astar materyalleri yaygın olarak kullanılmaktadır.

Pisani ve ark. $^{34}$ çalışmalarında 32 hastanın alt protezlerine yumuşak astar materyali uygulanmasını takiben 3ay süre sonrasında hastaların ağız sağlığı ile bağlantılı hayat kriterlerinin (OHRQoL) tümünü olumlu yönde etkilediğini belirtmişlerdir.

Bu materyaller, özellikle doku uyumunun bozulduğu ileri yaşlardaki hastalarda, hareketli protezlerde ve sınırlı sürelerde kullanılan malzemelerdir. ${ }^{35}$ Silikon esaslı yumuşak astar materyalleri, dokuların iyi tole- rans göstermeleri ve kullanım sürelerinin uzunluğu ile günümüzde en iyi özelliklere sahip olan yumuşak astar materyalleridir. Akıcı kıvamdan, koyu bir macuna kadar değişebilen viskoziteye sahiptirler. ${ }^{36}$ Silikon esaslı astar materyallerinin yapıları $50^{\circ} \mathrm{C}$ ve $+200^{\circ} \mathrm{C}$ arasında değişmediğinden ve asit, baz gibi birtakım kimyasal maddelere yapıları gereği dirençli olduklarından kimyasal etkilere karşı dirençlidirler. ${ }^{23}$ Yapıları nedeniyle esnek olan bu materyaller esnekliklerini uzun süre korudukları için daimi yumuşak astar materyali olarak kullanılabilirler. ${ }^{37}$

Doku düzenleyiciler; kuvvet dağılımının dengelenmesi amacı ile protezin iç yüzeyine geçici olarak uygulanan, fiziksel ve kimyasal olarak daimi yumuşak atar materyallerinden farklılık gösteren ve materyalin sertleşmesine yol açan çapraz bağlı reaksiyonlar meydana getirmeyip, jel hale dönüşen malzemelerdir. ${ }^{38}$

Yumuşak astar materyallerinin su emmeleri ve çözünürlükleri; boyutsal değişiklik, reziliens kaybı, renklenme, kötü koku ve akrilik kaideden ayrılmaya neden olmaktadır. Materyalin su emmesi; hidrofobisite derecesine ve porozitesine bağlıdır. ${ }^{39}$ Silikon esaslı yumuşak astar materyallerin yüksek hidrofobisitelerinden dolayı akrilik esaslı yumuşak astar materyallerinden daha az su emmerler. ${ }^{39}$ Hayakawa ve ark. ${ }^{39}$ çalışmalarında çözünürlüğün, su içerisinde iken bileşen kaybı anlamına geldiğini ve akrilik esaslı yumuşak astar materyallerinden plastizörlerin ve artık monomerlerin dışarı çıkmasının klinik problemlere yol açtığını belirtmişlerdir.

Hayakawa ve ark. ${ }^{39} 2003$ yılında poliizopren esaslı,ışıkla sertleşen yumuşak astar materyali Clearfit LC' nin klinik açıdan önemli özelliklerini piyasadaki diğer dört yumuşak astar materyaliyle karşılaştırdıkları çalışmalarında; 5 adet farklı yumuşak astar materyalini incelemişlerdir. (Clearfit LC (Kuraray Co. Osaka, Japan) (poliizopren esaslı), Super-soft (GC Lab Tech. Inc. Illınois,USA) (yumuşak akrilik), Soften (Kamemizu Chem. Co. Osaka, Japan) (yumuşak akrilik), Molloplast B (Detax,Ettlingen ,Germany) (silikon esaslı), Sofreliner (Tokuyama Corp. Tokyo, Japan) (silikon esaslı), Acron (GC Dental product Corp. Aichi,Japan) (PMMA rezin)). Her gruptan 5 adet $20 \mathrm{~mm}$. çapında, $1 \mathrm{~mm}$. kalınlığında hazırlanan disk şeklindeki numuneler, üretici firma talimatlarına göre hazırlanarak, 37 derece distile suda 7 gün bekletildikten sonra su emme ve çözünürlük ölçümleri yapılmıştır. Akrilik esaslı yumuşak astar materyalleri olan Super-soft ve Soften 
diğer 3 yumuşak astar materyalllerinden daha fazla su emme ve çözünürlük özellikleri göstermişlerdir. Clearfit LC' nin su emme değeri, heriki akrilik esaslı yumuşak astar materyallerinin değerlerinin yarısından az ve çözünürlüğü ise Molloplast B ile aynı bulunmuştur.

İdeal bir yumuşak astar maddesi salınabilir komponent içermemeli ve düşük bir su emilimine sahip olmalıdır. ${ }^{40}$ Kazanji ve ark. ${ }^{41}$ Molloplast-B dışındaki yumuşak astar maddelerinin yapay tükürükte distile sudan daha fazla çözünürlük gösterdiklerini saptamışlardır. Dinçkal ve ark. ${ }^{42}$ akrilik ve silikon esaslı yumuşak astar maddelerinin farklı solüsyonlar (yapay tükürük, distile su ve protez temizleyiciler) içindeki emilim ve çözünürlük yüzdelerini karşılaştırdıkları çalışmada; akrilik reçine esaslı olan yumuşak astar maddelerinin, silikon esaslı olan Molloplast-B'den daha fazla çözünürlük ve emilim gösterdiklerini bildirmişlerdir.

Yumuşak astar materyallerinin çözünürlüğü ile ilgili bir diğer çalışmada; Parr ve ark. ${ }^{43}$ tarafından 2002 yılında yapıımıştır. Çalışmada, iki farklı polimerizasyon tipindeki (otopolimerize ve konvansiyonel laboratuarda hazırlanan) iki yeni silikon esaslı yumuşak astar materyalinin fiziksel özelliklerindeki (sertlik, su emme ve çözünürlük) değişiklikler incelenmiştir. Bu çalışmada Luci-Soft (laboratuarda hazırlanan silikon esaslı yumuşak astar materyali) ve Tokuyama Soft Relining Paste (Otopolimerize silikon esaslı yumuşak astar materyali) silikon esaslı yumuşak astar materyalleri kullanılmıştır. 60 adet bar şeklinde, 44 × 8,5 x 1,2 mm. kalınlığında numuneler firma talimatlarına göre hazırlanarak, 37 derece distile suda bekletildikten sonra 1 gün, 1 hafta, 1 ay, 6 ay ve 1 yıl sonra sudan çıkarılmış ve tartılmıştır. Sonrasında numuneler oda ISısındaki fırına konulmuş, stabil bir ağırlık değeri elde edilene kadar numunelerin günlük ağırlık ölçümleri yapılarak su emme ve çözünürlük ölçümleri yapılmıştır. Laboratuarda hazırlanan silikon esaslı yumuşak astar materyali Luci-Soft'un çözünürlük değerleri, 1. ayda yükselmiş ve 6 aylık periyotta yüksek kalmıştır, daha sonra hafifçe azalmış ancak belirgin düşüşü 1.yılda göstermiştir. Otopolimerize silikon esaslı yumuşak astar materyali Tokuyama Soft Relining Paste ise başlangıçta düşük değerler göstermiş daha sonra hafifçe yükselip 1 hafta sonra stabil kalmıştır. Yalnızca 1 günlük zaman periyodunda her iki silikon esaslı yumuşak astar materyali için çözünürlük değerleri eşit bulunmuştur. Bu çalışmanın sonucunda; ISı ile polimerize olan silikon esası yumuşak astar materyalinde monomerden polimere dönüşümün daha fazla gerçekleşmesinin çözünürlüğünü azaltmış olabileceği düşünülmektedir. ${ }^{44}$

Yumuşak astar materyallerinin çözünürlüğü ile ilgili bir diğer çalışmada El-Hadary A. ve ark. ${ }^{44}$ nın, akrilik esaslı yumuşak astar materyali ile yeni piyasaya çıkan silikon esaslı yumuşak astar materyalinin su emme, çözünürlük ve gerilme direçlerini karşılaştırdıkları çalışmadır. Çalışmada; Luci-Soft (laboratuarda hazırlanan silikon esaslı yumuşak astar materyali) ile Permasoft (Otopolimerize akrilik esaslı yumuşak astar materyal) materyalleri kullanılmıştır. 45 mm.çapında, $1 \mathrm{~mm}$. kalınlığında 24 numune diskler şeklinde hazırlanmıştır. Sekizer numuneden oluşan 3 gruba bölünmüştür ve gruplarda 1 hafta, 4 hafta ve 6 hafta sonra ölçümler yapılmıştır. Çalışmanın sonucunda; laboratuarda hazırlanan silikon esaslı yumuşak astar materyali olan Luci-Soft'un tüm zaman periyodlarında otopolimerize akrilik esaslı yumuşak astar materyali Permasoft tan daha az su emme ve çözünürlük özellikleri gösterdiği bildirilmiştir.

Literatürde astar materyallerinin toksik etkilerinin incelendiği çalışmalar bulunmaktadır. Üç farklı materyalin [Triad (Dentsply, York, PA, USA), Astron LCH (Astron Dental, Wheeling, IL, USA) ve Extoral (Pro-Den Systems, Portland, OR, USA)] oral epitelyal hücrelere toksik etkilerinin incelendiği in vitro çalışmalarda toksik etkileri bulunduğu rapor edilmiştir. Genellikle dual-cure astarların, ışıkla polimerize materyallerden daha az sitotoksik oldukları bilinmesine rağmen ${ }^{45-47}$ çalışmalarda toksik etkilerin polimerizyon tipi ile değil materyallerin spesifik formülleri nedeniyle oluştuğu da ifade edilmiştir.

Dahl ve ark. ${ }^{48}$ hücre kültürü testleri kullanarak astar materyallerinin biouyumluluğunu değerlendirdikleri çalışmalarında da polimerizasyon tipi ile sitotoksite arasında ilişki bulamadıklarını bildirmişlerdir. Aynı çalışmada önceki çalışmalarda sitotoksik etkileri olduğu belirtilen Astron LC Hard astar materyalinin sitotoksik olmadığı rapor edilmiş ve önceki çalışmalarla 26,45-48 arada yaklaşık olarak 10 yıllık süre olduğu ve materyalin içeriğinin değiştirilmesinin sonucunda çözünen materyallerin azalttığı şeklinde ifade edilmiştir. Triad Dualine (dual-cure), Triad Resiline ve Triad VLC (Işıkla polimerize) astar materyalleri sitotoksik etkileri olduğu tespit edilmiştir.

Tay ve ark.da ${ }^{49}$ bir diğer hücre kültürü çalışmasında silikon esaslı yumuşak astar materyali Ufi-gel P (Voco) ve akrilik rezin Lucitone 550 dışındaki, akrilik 
esaslı yumuşak astar materyalleri (Dentuflex (Densell), Trusoft (Bosworth) ile doku düzenleyicinin (Dentusoft (Densell)) sitotoksik özellikleri olduğunu belirtmişlerdir.

Hücre kültür çalışmalarının sonuçlarının klinik ifadesini yorumlamak bazen oldukça güçtür. Müsin ve keratin tabakaları varlığı nedeniyle oral mukoza genellikle hücre kültürlerine nazaran toksik materyallere daha dirençlidir. ${ }^{49}$

Murata ve ark. ${ }^{50}$ doku düzenleyicilerin boyutsal stabiliteleri ve ağırlık değişimlerini inceledikleri çalışmalarında 6 farklı marka doku düzenleyici (Coe Comfort (CC), FItt (F), GC Soft-Liner (GS), Hydro-Cast (HC), SR-Ivoseal (SI), Visco-Gel (VG)) malzeme kullanmışlardır. Çalışmada numuneler hazırlandıktan 2 saat sonra tartılmış, $370 \mathrm{C}$ distile su içine yerleştirilmiş ve 8 , 24 saat ve 2, 4, 7, 14 ve 21 gün sonunda kurulanıp ölçülmüş, numunelerin emilim ve çözünürlük değerleri hesaplanmıştır. Çalışmanın sonucunda; doku düzenleyicilerin su emilimi ve çözünürlükleri arasında belirgin farklılıklar bulunmuştur. SR-Ivoseal (SI); en yüksek su emilimi $(\% 51,9)$ ve çözünürlüğü $(\% 18,8)$ göstermiş, Visco-Gel (VG); en düşük çözünürlük değerini (\% 4) göstermiş, FItt (F), GC Soft-Liner (GS), Hydro-Cast (HC) ve Visco-Gel (VG)'in su emilim yüzdeleri \% 3,5'un altında kalmış ve FItt (F), GC Soft-Liner (GS), Hydro-Cast (HC) ve Coe Comfort (CC)'un çözünürlük değerleri, su emilim değerlerinden yüksek bulunmuştur.

Pisani ve ark. ${ }^{51}$ deneysel bir temizleme solüsyonunun farklı yumuşak astar materyalleri üzerine etkilerini inceledikleri çalışmalarında hipoklorit solusyonunun iyonik solusyon olduğunu ve komponentlerin çözünürlüğüne neden olarak su emilimini sağladığı ve astar materyalinin sertliğini arttırdığını belirtmişlerdir.

Doldurucu içerikleri nedeniyle silikon bazlı astar materyalleri sıvı emerek zaman içerisinde daha fazla sertlik değerleri göstermektedirler. ${ }^{52}$ Sıvı emme özellikleri hidrofobisite derecesine ve materyalin porözitesine bağlıdır. ${ }^{53}$

Astar materyallerinin renk değişimi sıvı emilimi ile ilişkili bir özelliktir. ${ }^{54,55}$ Materyal komponentlerinin çözünürlüğü ve su emme özellikleri renk değişimine neden olmaktadır. ${ }^{51}$

Genellikle düşük absorbsiyon ve çözünürlük renk stabilitesini arttırıcı yönde rol oynamaktadır. ${ }^{44,56,57}$ Renk değişiklikleri sıklıkla materyalin yaşlanması ile ilişkilidir. ${ }^{2,57-59}$ Silikon esaslı astarlar, akrilik esaslı astar materyallerine göre belirgin bir şekilde daha iyi renk stabilitesi ve daha iyi su emilim ve çözünürlük özellikleri gösterirler. ${ }^{2}$

Mancuso ve ark. ${ }^{2}$ çalışmalarında akrilik esaslı yumuşak astar materyali (Trusoft) ve silikon esaslı yumuşak astar materyallerinin (Ufi Gel P, Ufi Gel SC and Dentusil) tümünün su emme ve çözünürlük özelliklerinin termal siklus işleminden etkilendiğini ancak Trusoft materyalinin en yüksek değerleri gösterdiğini rapor etmişlerdir. Plastizerin çözünürlüğü ve sonrasındaki su emmesi nedeniyle akrilik esaslı astarlar daha yüksek çözünürlük ve su emme değerleri göstermektedirler. ${ }^{60} \mathrm{Bu}$ durum akrilik esaslı yumuşak astar materyallerinin sağlamlığını tehlikeye atmakta ve uzun dönem astar materyali olarak kullanımını sınırlandırmaktadır. ${ }^{61}$

Akrilik esaslı yumuşak astarlar phthalate gibi plastizerlerle metakrilat polimerleri ve diğer aromatik karboksilik asit esterleri ve etonol içerirler. ${ }^{62,63}$ Munksgaard ve ark. ${ }^{64} 4$ yumuşak astar materyalinin plastizer kaybını 30 gün süre ile incelemişler ve tüm zamanlarda günlük sınırını aşar halde salındığını belirtmişlerdir. Graham ve ark. ${ }^{62}$ in vitro ve in vivo olarak plastizer kaybını belirtmişler ve plastizerlerin çözünürlüğünün tükrükle kıyaslandığında suda daha az olduğunu tespit etmişlerdir. Benzer bir sonuçla Munksgaard ve ark. ${ }^{64}$ da insan tükrüğünde suya göre 20 kat daha fazla phthalates çözündüğünü rapor etmişlerdir. ${ }^{49}$

\section{SONUÇ}

Çok sayıda çalışmanın sonuçları doğrultusunda yumuşak astar materyalleri yaşlandırma işlemleri sonrasında yüksek başlangıç sertlik değerleri, düşük su emilimi ve düşük çözünürlük değerleri ile renk değişiminde azalma olarak kendini göstermektedir. Avantajlar ve dezavantajlara sahip astar materyalinin seçimi klinik intiyaç doğrultusunda kullanım süresi ve beklenen sonuç dikkate alınarak yapılmalıdır.

\section{KAYNAKLAR}

1. Martori E, Montero RA, Gomis JM, Vinas M, Peraire M. Risk factors for denture related oral mucosal lesions in a geriatric population. J Prosthet Dent 2014;111:273-9.

2. Mancuso DN,Goiato MC, Zuccolotti BCR, Moreno A, dos Santos DM, Pesqueira AA. Effect of

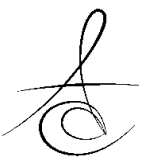


thermocycling on hardness, absorption, solubility and colour change of soft liners. Gerodontology 2012;29:215-9.

3. Tacir İH, Meşe A, Güzel KG. Fiber ile güçlendirmenin ve farklı polimerizasyon tekniklerinin, iki farklı protez kaide rezininin su emilim miktarına etkisi. Cumhuriyet Üni Diş Hek Fak Derg 2003;6:94-101.

4. Vallittu PK, Ruyter IE, Ekstrand K. Effect of water storage on the flexural properties of Eglass and silica fiber acrylic resin composite. Int J Prosthodont 1998;11:340-50.

5. Takahashi Y, Chai J, Kawaguchi M. Effect of water sorption on the resistance to plastic deformation of a denture base material relined with four different denture reline materials. Int J Prosthodont 1998;11:49-54.

6. Takahashi Y, Chai J, Kawaguchi M. Equilibrium strengths of denture polymers subjected to longterm water immersion. Int J Prosthodont 1999;12: 348-52.

7. Archadian N, Kawano F, Ohguri T et al. Flexural strength of rebased denture polymers. J Oral Rehabil 2000;27:690-6.

8. Lloyd $\mathrm{CH}$. The fracture toughness of dental composites. The environmental and temperature dependence of the stress intensification factor (KIC). J Oral Rehabil 1982;9:133-8.

9. Finoti LS, Machado AL, Carolina De Andrade Lima Chaves,ACPavarina ,Vergani CE Effect of longterm water immersion on the fracture toughness of denture base and reline resins. Gerodontology 2012;29:858-64.

10. Karaağaçlıoğlu L, Kalıpçılar B, Hasanreisoğlu U. Oda IsIsında polimerize olan enjeksiyon su emilimi, çözünürlük ve yüzey özelliklerinin değerlendirilmesi. A Ü Diş Hek Fak Derg 1988;15:59-63.

11. Karacaer Ö, Yaman DS, Değim GZ. Kompozit rezin materyallerin su emilimi ve çözünürlüğü. Atatürk Ü Diş Hek Fak Derg 2001;11:7-10.

12. Nalbant L, Burgaz Y. Enjeksiyon sistemi ve konvansiyonel mufla tekniği ile hazırlanan protez kaide materyallerinin su emme ve çözünürlük oranlarının değerlendirilmesi, A Ü Diş Hek Fak Derg 1990;17:333-7.

13. Miettinen VM, Vallittu PK, Docent DT. Water sorption and solubility of glass fiber-reinforced denture polymethyl methacrylate resin. J Prosthet Dent 1997;77:531-4.
14. Tsuchiya H, Hoshino $\mathrm{Y}$, Tajima K, Takagi N. Leaching and cytotoxicty of formaldehyde and methylmetacrylate from acrylic resin denture base materials. J Prosthet Dent 1994;71:618-24.

15. Rahal JS, Mesquita MF, Henriques GEP, Nobilo MAA. Influence of chemical and mechanical polishing on water sorption and solubility of denture base acrylic resins. Braz Dent J 2004;15: 225-30.

16. Lewis BB, Chestner SB. Formaldehyde in dentisty: a review of mutagenic and carcinogenic potential. J Am Dent Assoc 1981;103:429-34.

17. Budtz-Jorgensen E. Preventive Measures and Maintenance Care after Treatment. In: BudtzJorgensen $E$, eds. Prosthodontics for the elderly. In: Diagnosis and Treatment. 1st ed. Chicago;Quintessence Publishing:1999.p.229-57.

18. Chamberlain BB, Bernier SH, Bloem TJ, Razzoog ME. Denture plaque control and inflammation in the edentulous patient. J Prosthet Dent 1985;54:78-81.

19. Dills SS, Olshan AM, Goldner S, Brogdon C. Comparison of the antimicrobial capability of an abrasive paste and chemical-soak denture cleaners. J Prosthet Dent 1988;60:467-70.

20. Palenik $\mathrm{CJ}$, Miller $\mathrm{CH}$. In vitro testing of three denture-cleaning systems. J Prosthet Dent 1984; 51:751-4.

21. Raab FJ, Taylor CA, Bucher JA, Mann BL. Scanning electron microscopic examination of ultrasonic and effervescent methods of surface contaminant removal from complete dentures. J Prosthet Dent 1991;65:255-8.

22. Nakamoto K, Tamamoto M, Hamada T. Evaluation of denture cleansers with and without enzymes against Candida albicans. J Prosthet Dent 1991;66:792-5.

23. Turgut M, Polat NT, Doğan DÖ, Gürelik GM. Protez Temizleme Preparatlarının Kaide Akrilik Rezinlerinin Su Emilimi ve Çözünürlüğü Üzerine Etkileri. Türkiye Klinikleri ] Dental Sci 2008;14:137-41

24. Ural Ç, Şanal FA, Cenfiz S. Effect of Different Denture Cleansers on Surface Roughness of Denture Base Materials. Clinical Dentistry and Research 2011;35:14-20.

25. Polat TN, Karacaer O, Tezvergil A, Lassila LV, Vallittu PK. Water sorption, solubility and dimensional changes of denture base polymers 
reinforced with short glass fibers. J Biomater Appl 2003; 17:321-35.

26. Lefebvre CA, Knoernschild KL, Schuster GS. Cytotoxicity of eluates from light-polymerized denture base resins. J Prosthet Dent 1994;72:64450.

27. Dhir G, Berzins DW, Dhuru VB et al. Physical properties of denture base resins potentially resistant to Candida adhesion. J Prosthodont 2007; 16:465-72.

28. Kerby RE, Knobloch LA, Schricker $S$ et al. Synthesis and evaluation of modified urethane dimethacrylate resins with reduced water sorption and solubility. Dent Mater 2009;25:302-13.

29. Machado AL, Aaron D. Puckett, Larry C. Breeding, Amanda Fucci Wady Carlos Eduardo Vergani. Effect of thermocycling on the flexural and impact strength of urethane-based and high-impact denture base resins. Gerodontology 2012;29:31823.

30. Lai CP, Tsai MH, Chen M, Chang HS, Tay HH. Morphology and properties of denture acrylic resins cured by microwave energy and conventional water bath. Dent Mater 2004;20: 133-41.

31. Pfeiffer P, Rosenbauer EU. Residual methyl metacrylate monomer, water sorption and solubility of hypoallergenik denture base materials. J Prosthet Dent 2004;92:72-8.

32. Lassila LVJ, Vallıttu PK. Denture base polymer Alldent Sinomer: mechanical properties, water sorption and release of residual compounds. J Oral Rehabil 2001;28:607-13.

33. Takahashi Y, Chai J, Kawaguchi M. Effect of water sorption on the resistance to plastic deformation of a denture base material relined with four different denture reline materials. Int J Prosthodont 1998; 11:49-54.

34. Pisani MX, Malheiros-Segundo Ade $L$, Balbino KL, de Souza RF, Paranhos HF, da Silva CH. Oral health related quality of life of edentulous patients after denture relining with a silicone-based soft liner. Gerodontology 2012;29:474-80.

35. Atay A, Saraçlı M, Akyıl Ş, Tukay A, Oruç S. Candida Albicans'in Yumuşak Astar Maddelerine Olan Adezyonunun Modifiye Bir Teknikle İn-vitro Değerlendirilmesi. Hacettepe Diş Hek Fak Derg 2007;31:74-8.
36. Yanıkoğlu N. Yumuşak astar maddeleri ve özellikleri. Atatürk Üniv. Diş Hek Fak Der 20032004; 13,14:55-64.

37. Türker ŞB, Şener ID, Buğurman B. Silikon bazı daimi yumuşak astar materyallerinin renk stabilitesinin in vitro olarak değerlendirilmesi Atatürk Üniv Diş Hek Fak Derg 2008;18:53-9.

38. Zuluaga DJM, Velandia OCG, Clauija DMR. Denture-related stomatitis managed with tissue conditioner and hard autopolymerising reline material. Gerodontology 2011;28:258-63.

39. Hayakawa I, Keh ES, Morizawa M, Muraoka G, Hirano $S$. . A new polyisoprene-based light-curing denture soft lining material. J Dent 2003;31:26974.

40. Akşit KS, Mandalı G, Gürbüz Ö. Protetik tedavide bir yumuşak astar maddesi; Molloplast-B. Atatürk Üniv Diş Hek Fak Derg 2012;Supplement:5:113-22.

41. Kazanji MNM, Watkinson AC. Soft lining materials: their absorption of, and solubility in, artificial saliva. Br Dent J 1988;165:91-4.

42. Dinçkal Yanıkoğlu N, Yeşil Duymuş Z. Comparative study of water sorption and solubility of soft lining materials in the different solutions. Dent Mater J 2004;23:233-9.

43. Parr GR, Rueggeberg FA. In vitro hardness, water sorption and resin solubility of laboratoryprocessed and autopolymerized long term resilient denture liners over one year of water storage. J Prosthet Dent 2002;88:139-44.

44. El-Hadary A, Drummond JL. Comparative study of water sorption, solubility, and tensile bond strength of two soft lining materials. J Prosthet Dent 2000;83:356-61.

45. Lefebvre CA, Schuster GS, Caughman GB,Caughman WF. Effects of denture base resins on oral epithelial cells. Int J Prosthodont 1991;4: 371-6.

46. Barron DJ, Schuster GS, Caughman GB, Lefebvre CA. Biocompatibility of visible light-polymerized denture base resins. Int J Prosthodont 1993;6: 495-501.

47. Lefebvre CA, Schuster GS. Biocompatibility of visible light-cured resin systems in prosthodontics. J Prosthet Dent 1994;71:178-85.

48. Dahl JE, Frangou-Polyzois MJ, Gregory L. Polyzois GL. In vitro biocompatibility of denture relining materials. Gerodontology 2006;23;17-22.

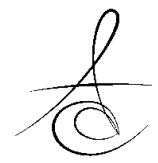


49. Tay LY, Herrera DR, Quishida CC, Carloz IZ, Jorge $\mathrm{JH}$. Effect of water storage and heat treatment on the cytotoxicity of soft liners. Gerodontology 2012; 29:275-80.

50. Murata $H$, Kawamura M, Hamada $T$, Saleh $S$, Kresnoadi $U$, Toki K. Dimensional stability and weight changes of tissue conditioners. J Oral Rehabil. 2001;28:918-23.

51. Pisani MX, daSilva $\mathrm{CH}$, Paranhos HF, Souza RF, Macedo AP. Evaluation of experimental cleanser solution of Ricinus communis: effect on soft denture liner properties. Gerodontology 2012;29: 179-85.

52. Pisani $M X$, da Silva $C H$, de Malheiros-Segundo $A L$, Macedo AP, Paranhos HF. Bond strength and degree of infiltration between acrylic resin/denture liner after immersion in effervescent denture cleanser. J Prosthodont 2009;18:123-9.

53. Mante FK, Mante MO, Petropolous VC. In vitro changes in hardness of sealed resilient lining materials on immersion in various fluids. J Prosthodont 2008;17:384-91.

54. Jin C, Nikawa HS, Makihira T, Hamada T, HM, Murata $\mathrm{H}$. Changes in surface roughness and color stability of denture lining materials caused by denture cleansers. J Oral Rehabil 2003;30:125-30.

55. Sarac, D, Sarac, YS, Kurt M, Yuzbasioglu E. The of denture cleansers on soft denture liners colored by food colorant solutions. J Prosthodont 2007;16: 185-91.

56. Mancuso DN, Goiato MC, Zuccolotti BCR, Moreno A, Santos DM. Evaluation of hardness and colour change of soft liners after accelerated ageing. Prim Dent Care 2009;16:127-30.

58. Wagner WC, Kawano F, Dootz ER, Koran AIII. Dynamic viscoelastic properties of processed soft denture liners. Part II. Effect ageing. J Prosthet Dent 1995;74:299-304.

59. Polysois GL, Yannikakis SA, Zissis AJ, Demetrious PP. Color changes of denture base materials after disinfection and sterilization immersion. Int J Prosthodont 1997;10:83-9.

60. Oguz S, Mutluay MM, Dogan OM, Bek B. Color change evaluation of denture soft lining materials in coffee and tea. J Dent Mater 2007;26:209-16.
61. Aziz T, Waters M, Jagger R. Development of a new poly(dimethylsiloxane) maxillofacial prosthetic material. J Biomed Mater Res B Appl Biomater 2003;65:252-61.

62. Graham BS,Jones DW, Sutow EJ. An in vivo and in vitro study of the loss of plasticizer from soft polymer-gel materials. J Dent Res 1991;70:870-3.

63. Hashimoto Y, Tanaka J, Suzuki K, Nakamura M. Cytocompatibility of a tissue conditioner containing vinyl ester as a plasticizer. Dent Mater J 2007;26:785-91.

64. Munksgaard EC. Leaching of plasticizers from temporary denture soft lining materials. Eur J Oral Sci 2004;112:101-4.

\section{Yazışma Adresi}

Yrd. Doç. Dr. Işıl Damla ŞENER YAMANER

İstanbul Aydın Üniversitesi

Diş Hekimliği Fakültesi

Protetik Diş Tedavisi Anabilim Dalı

Florya Yerleşkesi İnönü Cad. No:38

Küçükçekmece İstanbul

Tel: 02124441 428-29548

e-posta: isildamlasener@gmail.com 